\title{
Trophic ecology of the European anchovy Engraulis encrasicolus in the Catalan Sea (northwest Mediterranean)
}

\author{
Sergi Tudela*, Isabel Palomera \\ Institut de Ciències del Mar (CSIC), Plaça del Mar s/n, E-08039 Barcelona, Spain
}

\begin{abstract}
Analysis of adult anchovy samples collected in the Catalan Sea during the spawning periods in 1994 and 1995 showed that feeding activity by this engraulid was mainly diurnal, taking place particularly after noon. Copepods and other small prey were primary dietary items, the former presumably being concentrated at the level of the deep chlorophyll maximum during daytime. At night only sporadic consumption of large prey items, mostly decapod larvae and mysids, was recorded. The feeding pattern described results in spatio-temporal segregation of feeding and spawning activity and may account for the absence of cannibalism on anchovy eggs. An assessment of the impact of consumption by the anchovy population in the Catalan Sea on zooplankton production underscored the major role played by this species in channelling energy of the pelagic food webs to higher trophic levels.
\end{abstract}

KEY WORDS: Engraulis encrasicolus . Trophic ecology Pelagic ecosystem Energy flows . NW Mediterranean

\section{INTRODUCTION}

The European anchovy Engraulis encrasicolus is a small pelagic fish that is widely distributed throughout the Mediterranean Sea (Palomera \& Rubies 1996). Maximum abundance levels in the northwest Mediterranean Sea are recorded during the spawning period (April to October) over the continental shelf, in areas influenced by freshwater inputs from large rivers (Palomera 1992, García \& Palomera 1996). Three main spawning areas are known in this region: one off southern Catalonia (NE Spain) in the vicinity of the Ebro River, another in the vicinity of the Gulf of Lions / northern Catalonia, under the influence of the Rhone River, and the third on the continental shelf opposite Liguria and Tuscany, Italy, in the vicinity of the Tuscan Archipelago. Most of the biomass of this species in the region is concentrated in the first 2 areas, where the greater part of the commercial catches are taken (García \& Palomera 1996, Pertierra \& Lleonart 1996).

•E-mail: studela@icm.csic.es
The vast majority of research on the trophic ecology of adults of this species (Okul 1940, Nikitin 1946, Mikhman \& Tomanovich 1978, Sirotenko \& Danilevskiy 1978, Bulgakova 1993a, b) has focused solely on the Black Sea-Sea of Azov, a region clearly differentiated from the rest of the Mediterranean Basin by its highly specific hydrological and ecological conditions. Although this research, and other work dealing with congeneric species (Hayasi 1967. Angelescu \& Anganuzzi 1981, Koslow 1981, James 1987), are in agreement on the predominance of zooplankton in the diet, there is no consensus concerning the spatio-temporal aspects of feeding behaviour in these species. Thus, different patterns of feeding behaviour have been described for a given species depending on the author, study area, year, and period considered.

The only paper dealing with the feeding ecology of anchovy in the Mediterranean Basin (excluding the Black Sea-Sea of Azov region) is a quantitative study of the feeding of anchovy during the spawning period off southern Catalonia (Catalan Sea, NW Mediterranean Sea) describing a typically diurnal feeding pattern 
(Tudela \& Palomera 1995). The present paper greatly expands the previous study and provides a broad overview of this species' trophic behaviour. It contains a study of the qualitative and quantitative aspects of feeding by the adult anchovy spawning stock in a welldefined geographic area during the spawning periods in 2 consecutive years. The present study takes a dynamic approach, including spatial and temporal components, with a view to establishing a comprehensive picture of the trophic ecology of this species linking hydrological structures and production during the spawning period, prey biology and ecology, nychthemeral cycles affecting vertical migrations and spawning activity, etc To this end, some key topics, such as the diel cycle of feeding, the qualitative composition of the diet and the extent of occurrence of egg cannibalism, were addressed.

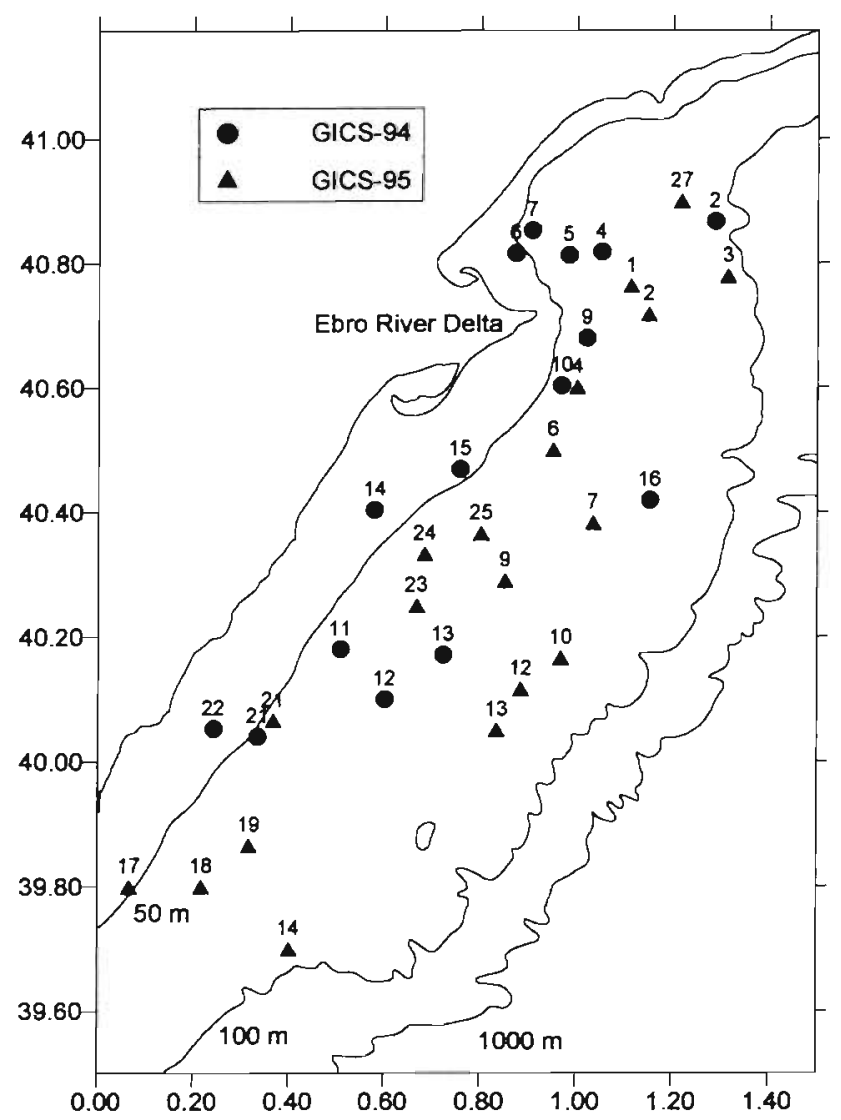

Fig. 1 Geographic distribution of tows on the GICS-94 and GICS-95 surveys in which anchovy were captured in the Catalan Sea, NW Mediterranean
Table 1 Sampling information for anchovy hauls on the GICS-95 survey

\begin{tabular}{|c|c|c|c|c|c|c|}
\hline \multirow[t]{2}{*}{ Sample } & \multicolumn{2}{|c|}{ Starting location } & \multirow{2}{*}{$\begin{array}{c}\text { Date } \\
(1995)\end{array}$} & \multirow{2}{*}{$\begin{array}{c}\text { Mean time } \\
\text { of capture } \\
\text { (h GMT) }\end{array}$} & \multirow{2}{*}{$\begin{array}{c}\text { Tow } \\
\text { duration } \\
\text { (min) }\end{array}$} & \multirow{2}{*}{$\begin{array}{c}\text { Starting } \\
\text { depth } \\
\text { (m) }\end{array}$} \\
\hline & $N$ & $E$ & & & & \\
\hline 1 & $40^{\circ} 45^{\prime}$ & $01^{\circ} 06^{\prime}$ & 23 May & $12: 13$ & 40 & 95 \\
\hline 2 & $40^{\circ} 43^{\prime}$ & $01^{\circ} 08^{\prime}$ & 23 May & $14: 17$ & 30 & 95 \\
\hline 3 & $40^{\circ} 46^{\prime}$ & $01^{\circ} 18^{\prime}$ & $23 \mathrm{May}$ & $17: 03$ & 23 & 128 \\
\hline 4 & $40^{\circ} 36^{\prime}$ & $01^{\circ} 00^{\prime}$ & 24 May & $05: 28$ & 24 & 68 \\
\hline 6 & $40^{\circ} 30^{\prime}$ & $00^{\circ} 57^{\prime}$ & $24 \mathrm{May}$ & $08: 30$ & 40 & 72 \\
\hline 7 & $40^{\circ} 23^{\prime}$ & $01^{\circ} 02^{\prime}$ & 24 May & $11: 08$ & 37 & 85 \\
\hline 9 & $40^{\circ} 17^{\prime}$ & $00^{\circ} 51^{\prime}$ & 25 May & $06: 53$ & 23 & 77 \\
\hline 10 & $40^{\circ} 10^{\prime}$ & $00^{\circ} 58^{\prime}$ & 25 May & $08: 42$ & 41 & 88 \\
\hline 12 & $40^{\circ} 07^{\prime}$ & $00^{\circ} 53^{\prime}$ & $25 \mathrm{May}$ & $17: 47$ & 26 & 85 \\
\hline 13 & $40^{\circ} 03^{\prime}$ & $00^{\circ} 50^{\prime}$ & $26 \mathrm{May}$ & $00: 15$ & 30 & 88 \\
\hline 14 & $39^{\circ} 42^{\prime}$ & $00^{\circ} 24^{\prime}$ & $26 \mathrm{May}$ & $09: 46$ & 45 & 1.04 \\
\hline 17 & $39^{\circ} 48^{\prime}$ & $00^{\circ} 04^{\prime}$ & 27 May & $02: 27$ & 25 & 61 \\
\hline 18 & $39^{\circ} 48^{\prime}$ & $00^{\circ} 13^{\prime}$ & 27 May & $04: 23$ & 27 & 79 \\
\hline 19 & $39^{\circ} 52^{\prime}$ & $00^{\circ} 19^{\prime}$ & 27 May & $06: 21$ & 32 & 72 \\
\hline 21 & $40^{\circ} 04^{\prime}$ & $00^{\circ} 22^{\prime}$ & 27 May & $09: 14$ & 21 & 54 \\
\hline 23 & $40^{\circ} 15^{\prime}$ & $00^{\circ} 40^{\prime}$ & 27 May & $19: 58$ & 16 & 68 \\
\hline 24 & $40^{\circ} 20^{\prime}$ & $00^{\circ} 41^{\prime}$ & $27 \mathrm{May}$ & $21: 11$ & 27 & 61 \\
\hline 25 & $40^{\circ} 22^{\prime}$ & $00^{\circ} 48^{\prime}$ & 27 May & $22: 26$ & 27 & 67 \\
\hline 27 & $40^{\circ} 54^{\prime}$ & $01^{\circ} 13^{\prime}$ & 28 May & $07: 25$ & 16 & 85 \\
\hline
\end{tabular}

Finally, the quantification of daily ration was used to determine, for the first time in this species, the share of production by lower trophic levels consumed by the anchovy population. Determination of this energy flow will significantly improve our understanding of the overall working of the pelagic food web in the Mediterranean.

\section{MATERIALS AND METHODS}

The samples used in this study were collected on 2 oceanographic surveys conducted in consecutive years on the continental shelf in the vicinity of the mouth of the Ebro River in the Catalan Sea (Fig. 1). The first survey (GICS-94) was carried out between 26 and 30 May 1994, and the second (GICS-95) was carried out between 23 and 28 May 1995. The sampling period coincided with peak spawning by the species in the study area. While the spawning period in the region runs from April to October, $86 \%$ of spawning takes place in May and June (Palomera 1992). Samples were collected on board a commercial fishing vessel equipped with a midwater trawl on the continental shelf, where the bulk of spawning occurs (Palomera 1992). Every effort was made to distribute tows throughout the day in order to cover the entire diel cycle.

Data for the GICS-94 survey have been described in Tudela \& Palomera (1995). On the GICS-95 survey, anchovy were taken in 19 of the 27 hauls (Table 1). Upon capture, individuals were fixed immediately in 
$10 \%$ formalin buffered to neutral $\mathrm{pH}$ using a phosphate solution. Initial sample size permitting, 2 random subsamples of 20 individuals each were taken for quantitative and qualitative analyses.

The quantitative analysis began with calculation of the mean stomach fullness index values for each of the samples on the GICS-95 survey. The methodology employed was the same as that used to analyse the samples from the GICS-94 survey and has been described in detail in Tudela \& Palomera (1995). Mean stomach fullness values by sex for each sample in 1995 were compared by analysis of variance (ANOVA) after applying Bartlett's test for homoscedasticity of the data. Quantitative determinations of food consumption were performed using the method of Elliott \& Persson (1978), which is based on an exponential model of digestion. Thus, food consumption for a given time interval $t$ can be described by the equation:

$$
C_{t}=\frac{R t\left(S_{t}-S_{0} \mathrm{e}^{-R t}\right)}{1-\mathrm{e}^{-R t}}
$$

where $C_{l}$ is food consumption, $S_{t}$ is the mean stomach fullness value at time $t, S_{0}$ is the mean stomach fullness value at time 0 , and $R$ is the instantaneous gastric evacuation rate. The instantaneous gastric evacuation rate is calculated from the stomach fullness values over a period of fasting after a period of heavy feeding, using the equation:

$$
\ln S_{t}=\ln S_{0}-R t
$$

where $t$ is the period of fasting considered and $S_{0}$ and $S$, the mean stomach fullness values at the start and end of that period. To calculate the most suitable evacuation rate for the GICS-95 survey, Eq. (2) was applied to each pair of consecutive samples taken during the daily period of fasting as determined by studying the diel cycle and the analysis of digestion of the stomach contents. From all the values calculated, the most reliable was selected on the basis of the following criteria: (1) The shortest time interval between the 2 samples. (2) The greatest likelihood that both samples had been taken after peak feeding. (3) The qualitative composition of the stomach contents was similar. (4) Calculations involving samples with mean stomach fullness index values that were very low or close to 0 were discarded, inasmuch as the theoretical exponential model of digestion does not work well at low levels of stomach fullness.

Food consumption intensity during the day was studied by calculating consumption ( $E q$. 1) for each pair of consecutive samples collected on both surveys during the times of day when individuals were assumed to feed. In accordance with the requirements of the method of Elliott \& Persson (1978), only intervals shorter than $4 \mathrm{~h}$ were considered. These partial esti- mates of food consumption were used to calculate mean hourly feeding intensity by dividing the values by interval duration.

For the qualitative examination of feeding, between 10 and 20 stomachs were dissected for each tow on both cruises, the number depending on the mean level of stomach fullness in the samples. The contents of each stomach were first examined under a dissecting microscope, and the prey items belonging to the largest taxa (larger than 2 to $3 \mathrm{~mm}$ ) were separated out and, where possible, measured. This group of prey items was designated Group 1 . The remaining stomach contents for the individuals in each sample, consisting of prey items belonging to taxonomic groupings including small species or the early stages of larval development (Group 2), were mixed together. A subsample was then taken and examined under a dissecting microscope. A number of individual prey items considered sufficiently representative of the composition was then identified to the lowest possible taxonomic level. In addition, a variable number of prey items in each category in each sample were measured using an ocular micrometer $( \pm 0.01 \mathrm{~mm})$, making an effort to span the entire size range.

Affinities in the diet among all samples were assessed with correspondence analysis using the matrix of relative abundance (\%) data for the prey items in Group 2 comprising a proportion of at least $5 \%$ of the total prey items for the group in at least 1 sample. This method of multivariate analysis is based on distance $\chi^{2}$ and affords the advantage of allowing both populations and characteristics to be plotted concurrently in factorial space, such that the proximity of a characteristic to a given group of populations indicates higher frequency of the characteristic concerned in those populations (Cuadras 1991).

\section{RESULTS}

No differences in the stomach fullness index were found between the sexes in the samples of the GICS-95 survey (Table 2) at a $1 \%$ level of significance, the same results as for the 1994 samples (Tudela \& Palomera 1995). Since females in a stage of marked gonadal development (hydration prior to spawning) were present in sample 3 on the 1995 survey (17:03 h GMT), in addition to the normal sample, another sample containing only females in an advanced stage of gonadal development was collected. Spawning in this species takes place between 20:00 and 04:00 h GMT (García \& Palomera 1996, Motos 1996). A second ANOVA was run to compare the stomach fullness in the 10 males in the original sample with that in the 20 females in the additional sample to ascertain whether close proximity 
Table 2. Encraulis encrasicolus. Results of Bartlett's test for homoscedasticity and the ANOVA test for homogeneity of

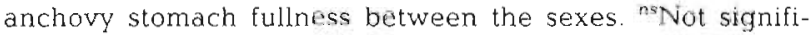
cant, 'significant at the $5 \%$ level, ${ }^{\prime}$ significant at the $1 \%$ level

\begin{tabular}{|c|c|c|c|c|c|c|}
\hline \multirow[t]{2}{*}{ Sample } & \multicolumn{3}{|c|}{ Bartlett } & \multicolumn{3}{|c|}{ ANOVA } \\
\hline & $\chi^{2}$ & df & $p$ & $F$ & df & $\mathrm{p}$ \\
\hline 1 & 1.5184 & 1 & $0.2178^{\mathrm{ns}}$ & 0.4368 & 1,18 & $0.5170^{\text {ns }}$ \\
\hline 2 & 0.0089 & 1 & $0.9245^{\text {ne }}$ & 0.1332 & 1,17 & $0.7195^{\mathrm{ns}}$ \\
\hline 3 & 0.4982 & 1 & $0.4802^{\mathrm{ns}}$ & 0.7855 & 1,18 & $0.3871^{\mathrm{ns}}$ \\
\hline 4 & 0.0457 & 1 & $0.8306^{n-}$ & 6.6899 & 1,18 & $0.0186^{\circ}$ \\
\hline 6 & 0.3080 & 1 & $0.5788^{\mathrm{ns}}$ & 1.9190 & $1,1.8$ & $0.1828^{\text {ns }}$ \\
\hline 7 & 0.5232 & 1 & $0.4694^{\text {ns }}$ & 0.0033 & 1,18 & $0.9546^{\mathrm{ns}}$ \\
\hline 9 & 0.1319 & 1 & $0.7163^{\mathrm{ns}}$ & 0.6281 & 1,18 & $0.4383^{\text {nis }}$ \\
\hline 10 & 0.2195 & 1 & $0.6394^{\mathrm{ns}}$ & 0.0517 & 1,18 & $0.8225^{\text {ns }}$ \\
\hline 12 & 0.0686 & 1 & $0.7933^{\mathrm{ns}}$ & 0.1628 & 1,9 & $0.6959^{\text {ns }}$ \\
\hline 13 & 0.9985 & 1 & $0.3176^{\text {ns }}$ & 0.7281 & 1,18 & $0.4047^{\mathrm{ns}}$ \\
\hline 14 & 1.3059 & 1 & $0.2531^{\text {ns }}$ & 0.3311 & 1,18 & $0.5721^{\mathrm{ns}}$ \\
\hline 17 & 0.3480 & 1 & $0.5552^{\mathrm{ns}}$ & 1.5760 & 1,18 & $0.2253^{\text {ns }}$ \\
\hline 18 & 2.5143 & 1 & $0.1128^{\mathrm{ns}}$ & 3.9510 & 1,18 & $0.0622^{\mathrm{ns}}$ \\
\hline 19 & 7.9736 & 1 & $0.0047^{\cdots}$ & 1.5552 & 1,18 & $0.2283^{\text {ns }}$ \\
\hline 21 & 0.4327 & 1 & $0.5106^{\text {ns }}$ & 0.2270 & 1,14 & $0.6410^{n / s}$ \\
\hline 23 & 0.1255 & 1 & $0.7231^{\mathrm{nh}}$ & 3.9844 & 1,18 & $0.0612^{\text {ns }}$ \\
\hline 24 & 0.6780 & 1 & $0.4102^{\mathrm{ns}}$ & 0.1834 & 1,18 & $0.6730^{\text {ns }}$ \\
\hline 25 & 0.9921 & 1 & $0.3192^{\mathrm{ns}}$ & 0.5670 & 1,18 & $0.4611^{\text {ns }}$ \\
\hline 27 & 0.3172 & 1 & $0.5732^{\text {ns }}$ & 0.0004 & 1,18 & $0.9830^{\text {ns }}$ \\
\hline
\end{tabular}

of spawning affected the females' feeding behaviour. The analysis was performed twice, once using total weight of females to estimate stomach fullness and once using somatic weight. The analysis showed that the increased weight of hydrated females did not affect the results of the comparative study. There were no significant differences in stomach fullness between the sexes in either case $\left(F_{1,28}=0.097, \mathrm{p}=0.75\right.$ and $F_{1,28}=$ $0.169, \mathrm{p}=0.68$ ).

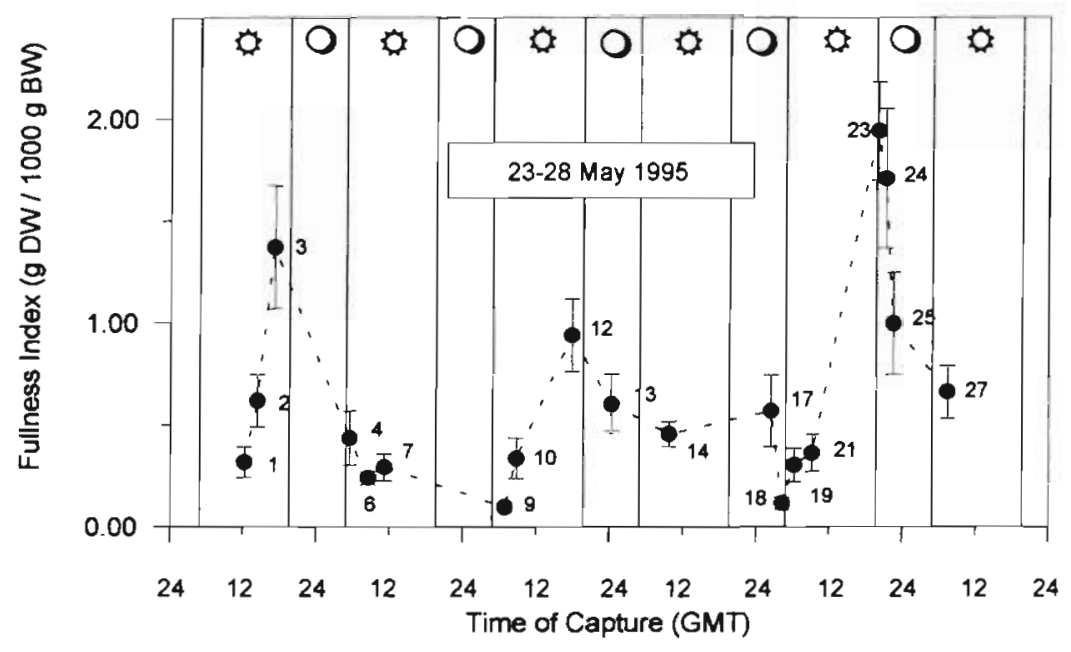

Fig 2. Engraulis encrasicolus. Mean values ( $\pm 95 \%$ confidence intervals) for anchovy stomach fullness in each of the samples on the GICS-95 survey vs time of day (light and dark cycles are indicated)
Fig. 2 plots the mean stomach fullness values for the samples on the GICS-95 survey on time of day and shows that the basic feeding pattern on the GICS-94 survey (Tudela \& Palomera 1995) was repeated at the same time of year during the spawning period the following year. This highlights the existence of a very pronounced diel cycle in which maximum levels of stomach fullness occur at sunset and minimum levels towards sunrise. These results reflect the classic pattern of diurnal feeding with a diel peak in stomach fullness (Eggers 1977). The combined plot of a composite day showing the mean stomach fullness values for the samples on both surveys (Fig. 3) reflects the diel feeding pattern even more clearly.

Since feeding activity in anchovy was diurnal, nocturnal samples from the period of fasting were used to calculate the instantaneous gastric evacuation rate $(R)$ to be applied on consumption values for the GICS-95 survey. From among all the possible combinations, the calculation for the short interval between samples 24 and 25 (1.25 h) was considered most reliable. Both samples were substantially after the feeding peak, the qualitative composition of the stomach contents in the samples was the same, and both levels of mean stomach fullness were rather high. The result obtained, $R=0.430 \mathrm{~h}^{-1}$, was quite similar to the value calculated by Tudela \& Palomera (1995) for the GICS-94 survey, $0.423 \mathrm{~h}^{-1}$

Fig. 4 graphically represents the combined feeding intensity values for each of the surveys versus time of day. Feeding intensity values based on any 2 consecutive samples were assigned to the midpoint of the time interval covered. Results show the increase in feeding intensity during daytime, a trend found on both surveys considered. Thus, consumption was low in the morning before 10:00 h GMT (between 0.136 and $0.230 \mathrm{~g} \mathrm{DW}$ $1000 \mathrm{~g}^{-1} \mathrm{BW} \mathrm{h} \mathrm{h}^{-1}$ ), rising to more than

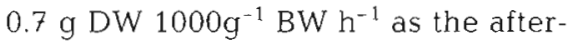
noon advanced. The feeding intensity values were quite similar during the 2 survey periods. On the 2 surveys, only sampling of the diel feeding cycle on 28 May 1994 was adequate for use in determining the daily ration, as described in Tudela \& Palomera (1995).

Tables $3 \& 4$ present the results of the analysis of the composition of the diet in the samples on the 2 surveys. Only qualitative information is shown for the higher taxa (Group 1), but the tables present the percentage abundance values for the prey items in Group 2 in each of the samples in relation to the total. Based on the results, 
Table 3. Engraulis encrasicolus. Qualitative composition of the stomach contents in the GICS-94 samples. The presence of each Group 1 taxon $(+)$ and the relative abundance $(\%)$ or presence $(+)$ of each Group 2 taxon (N: total number of individuals identified) and the size range, mean size, and number of measured prey items (in parentheses) are shown. In Group 1, the stomachs in samples 9 and 22 (not shown) contained only mysids. In Group 2, individuals of Clausocalanus furcatus and Paracalanus parvus were considered as a single category. Stomach fullness index: g DW $1000 \mathrm{~g}^{-1}$ wet BW For explanation of Groups 1 and 2 see 'Materials and methods'

\begin{tabular}{|c|c|c|c|c|c|c|c|c|c|c|c|c|c|c|}
\hline $\begin{array}{r}\text { Sample: } \\
\text { Time (h GMT): } \\
\text { Stomach fullness index: }\end{array}$ & $\begin{array}{c}2 \\
17: 06 \\
1.881\end{array}$ & $\begin{array}{c}4 \\
05: 38 \\
0.001\end{array}$ & $\begin{array}{c}5 \\
07: 25 \\
0.175\end{array}$ & $\begin{array}{c}6 \\
09: 59 \\
0.399\end{array}$ & $\begin{array}{c}7 \\
16: 10 \\
0.318\end{array}$ & $\begin{array}{l}10 \\
07: 08 \\
0.212\end{array}$ & $\begin{array}{c}11 \\
11: 39 \\
0.290\end{array}$ & $\begin{array}{c}12 \\
14: 43 \\
1.342\end{array}$ & $\begin{array}{c}13 \\
18: 13 \\
1.731\end{array}$ & $\begin{array}{c}14 \\
02: 42 \\
0.309\end{array}$ & $\begin{array}{c}16 \\
07: 55 \\
0.281\end{array}$ & $\begin{array}{c}21 \\
23: 21 \\
0.346\end{array}$ & $\begin{array}{l}\text { Size } \\
\text { range } \\
\text { (mm) }\end{array}$ & $\begin{array}{l}\text { Mean } \\
\text { size } \\
(\mathrm{mm})\end{array}$ \\
\hline \multicolumn{15}{|l|}{ Group 1} \\
\hline \multicolumn{15}{|l|}{ Appendiculara } \\
\hline Oikopleura sp. & & + & + & & & & & & & & & & $1.53-210$ & $1.74(8)$ \\
\hline \multicolumn{15}{|l|}{ Crustaced } \\
\hline \multicolumn{15}{|l|}{ Amphipoda } \\
\hline Platyscelus ovoides & & & & & & & & & & & + & & 2.11 & $2.11(1)$ \\
\hline Unidentified Hyperidea & + & & & & & & & & & & & & $2.30-4.22$ & $3.26(2)$ \\
\hline Westwoodilla rectirostris & & & & & & & & & & + & & & 2.5 & $2.5(1)$ \\
\hline Unidentified Gammaride & & & & & & & & & & & & + & 2.5 & 2.5 (1) \\
\hline \multicolumn{15}{|l|}{ Cumacea } \\
\hline Unidentified Leuconidae & & & & & & & & & & + & & & 4 & $4 \quad(1)$ \\
\hline \multicolumn{15}{|l|}{ Decapoda } \\
\hline Procesa sp. & & & & & & & & & & & & + & 9.22 & $9.22(1)$ \\
\hline Brachyura larvae & + & & & & + & & & + & + & & & & $1.04-2.50$ & $1.86(14)$ \\
\hline Crangonidae larvae & & & & & & & & & & + & & & 5.6 & $5.6(1)$ \\
\hline Unidentified larvae & + & & & + & + & & + & + & + & + & + & + & $1.54-5.12$ & $2.90\{40\}$ \\
\hline \multicolumn{15}{|l|}{ Euphausiaced } \\
\hline Unidentified larvae & & + & & & & & & & & & & & 2.11 & $2.11(1)$ \\
\hline \multicolumn{15}{|l|}{ Mysidacea } \\
\hline Erythrops sp. & & & & & & & & & & + & & & 3.52 & $3.52(1)$ \\
\hline Leptomysis $\mathrm{sp}$ & & & & & & & & & & + & & + & $11-13.5$ & $12.8 \quad(5)$ \\
\hline Unidentified mysidacea & & + & & + & + & + & + & & & + & & + & $2.49-11.79$ & 7.31 \\
\hline \multicolumn{15}{|l|}{ Polychaeta } \\
\hline Unidentified polychaeta & & & + & + & + & + & & & & & & & $0.38-5.12$ & $177(7)$ \\
\hline \multicolumn{15}{|l|}{ Vertebrata } \\
\hline Anchovy eggs & & & & & & & & + & + & & & & $1.19-1.30$ & $1.27(2)$ \\
\hline Unidentified fish eggs & & & & + & + & & + & + & + & & + & & $0.77-1.15$ & $1.03(33)$ \\
\hline \multicolumn{15}{|l|}{ Group 2} \\
\hline \multicolumn{15}{|l|}{ Crustacea } \\
\hline Eggs & & & & & & & & 5.02 & & & & & 0.23 & $0.23(3)$ \\
\hline Unidentified nauplı & & & 0.57 & & & & 2.69 & & & & & + & $0.19-0.38$ & $0.30(5)$ \\
\hline \multicolumn{15}{|l|}{ Cladocera } \\
\hline Evadne spinfera & & & & & & & & & 2.00 & & & + & $0.69-0.77$ & $0.74(3)$ \\
\hline Podon intermedius & & & & 1.16 & & & 4.61 & 11.58 & 24.06 & + & & + & $0.57-0.96$ & $0.77(26)$ \\
\hline Copepoda & & & & & & & & & & & & & & \\
\hline Acartia claus! & & + & & 2.71 & & & 1.53 & & 0.57 & & & + & $0.96-1.15$ & $1.03(9)$ \\
\hline Calanus helgolandicus & & & & & + & & & & & & 2.29 & & $2.11-2.76$ & $2.44(7)$ \\
\hline Calocalanus sp. & & & & 1.16 & & & & & & & & & 0.57 & $0.57(1)$ \\
\hline Candacia armota & & + & & + & 0.69 & & 0.38 & & & & & & $1.73-2.3$ & $2.08(4)$ \\
\hline Centropages typicus & 8907 & t & 8.67 & 19.76 & 208 & 4.69 & 4.23 & 33.59 & 7.16 & + & 61.14 & + & $0.61-1.53$ & $1.24(61)$ \\
\hline $\begin{array}{l}\text { Clausocalanus furcatus } \\
\& \text { Paracalanus parvus }\end{array}$ & & + & 1.15 & 968 & & 8.05 & 13.84 & 3.09 & 6.30 & & 10.85 & + & $0.50-1.22$ & $0.76(48)$ \\
\hline Corycaeidae & & + & 6.93 & 6.97 & 9.02 & 8.05 & 3.07 & 3.86 & 4.58 & & 2.29 & + & $0.61-1.53$ & $0.86(47)$ \\
\hline Euterpina acutifrons & 0.54 & + & 346 & 17.44 & 4.16 & 42.28 & 10.00 & & 2.00 & + & & + & $0.31-0.76$ & $0.54(41)$ \\
\hline Microsetella rosea & & + & 54.33 & 15.89 & 62.5 & 1.34 & 5.00 & & & & & + & $0.46-0.84$ & $0.68(23)$ \\
\hline Monstrilla sp. & & + & & + & & & & & & & & & $153-3.64$ & $2.58(2)$ \\
\hline Oncaea spp. & & + & 13.87 & 14.72 & 13.88 & 28.18 & 15.00 & 28.96 & 4499 & + & 10.86 & + & $0.34-1.07$ & $0.55(71)$ \\
\hline Pleuromammasp & 6.55 & & & 0.38 & & & & 0.39 & & & 1.71 & & 3.07 & $3.07(3)$ \\
\hline Saphirma sp. & + & & & & & & & & & & & & 6.72 & $6.72(1)$ \\
\hline Temora stylffera & 0.54 & & & & 0.69 & & 0.76 & 4.63 & & + & 5.71 & + & $0.96-1.54$ & $1.23|9|$ \\
\hline Unidentified copepoda & 1.63 & + & 4.04 & 6.97 & 3.47 & 2.68 & 9.23 & 1.16 & 1.72 & + & 5.14 & & $0.69-4.6$ & - \\
\hline Ostracoda & & & & & & & & & & & & & & \\
\hline Conchoecia oblusata & & & 0.57 & & & & & & & & & & 0.77 & $0.77(1)$ \\
\hline Mollusca & & & & & & & & & & & & & & \\
\hline Pelecypoda larvae & 1.63 & & 5.78 & 3.87 & 2.77 & 4.69 & 24.61 & 7.72 & 6.59 & + & & & $0.19-0.65$ & $0.31(39)$ \\
\hline Prosobranchia larvae & & & 0.57 & 0.38 & 0.69 & & 5.00 & & & + & & & $0.23-0.69$ & $0.41(8)$ \\
\hline $\mathrm{N}$ & 189 & & 173 & 258 & 144 & 149 & 260 & 259 & 349 & & 175 & & & \\
\hline
\end{tabular}




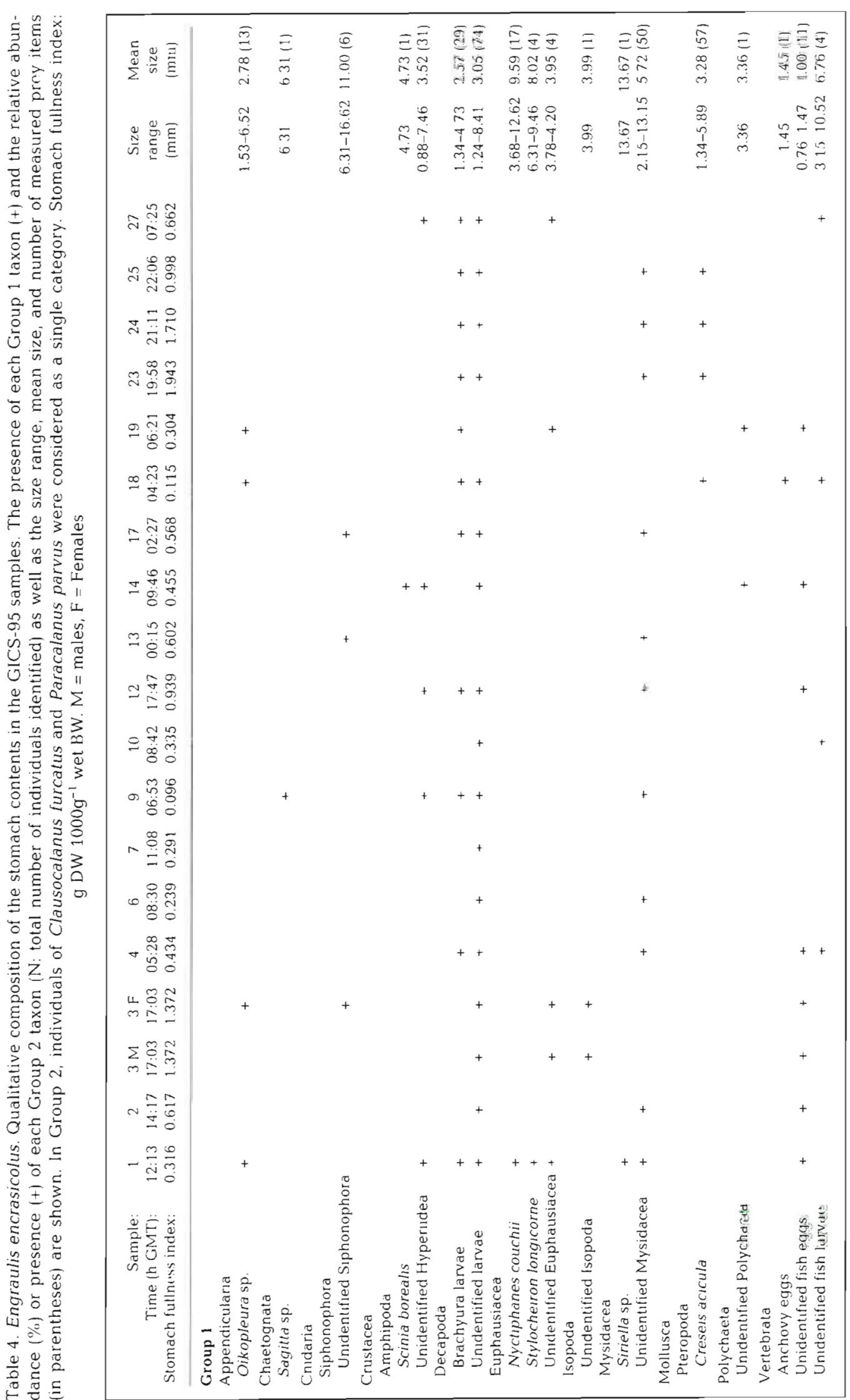




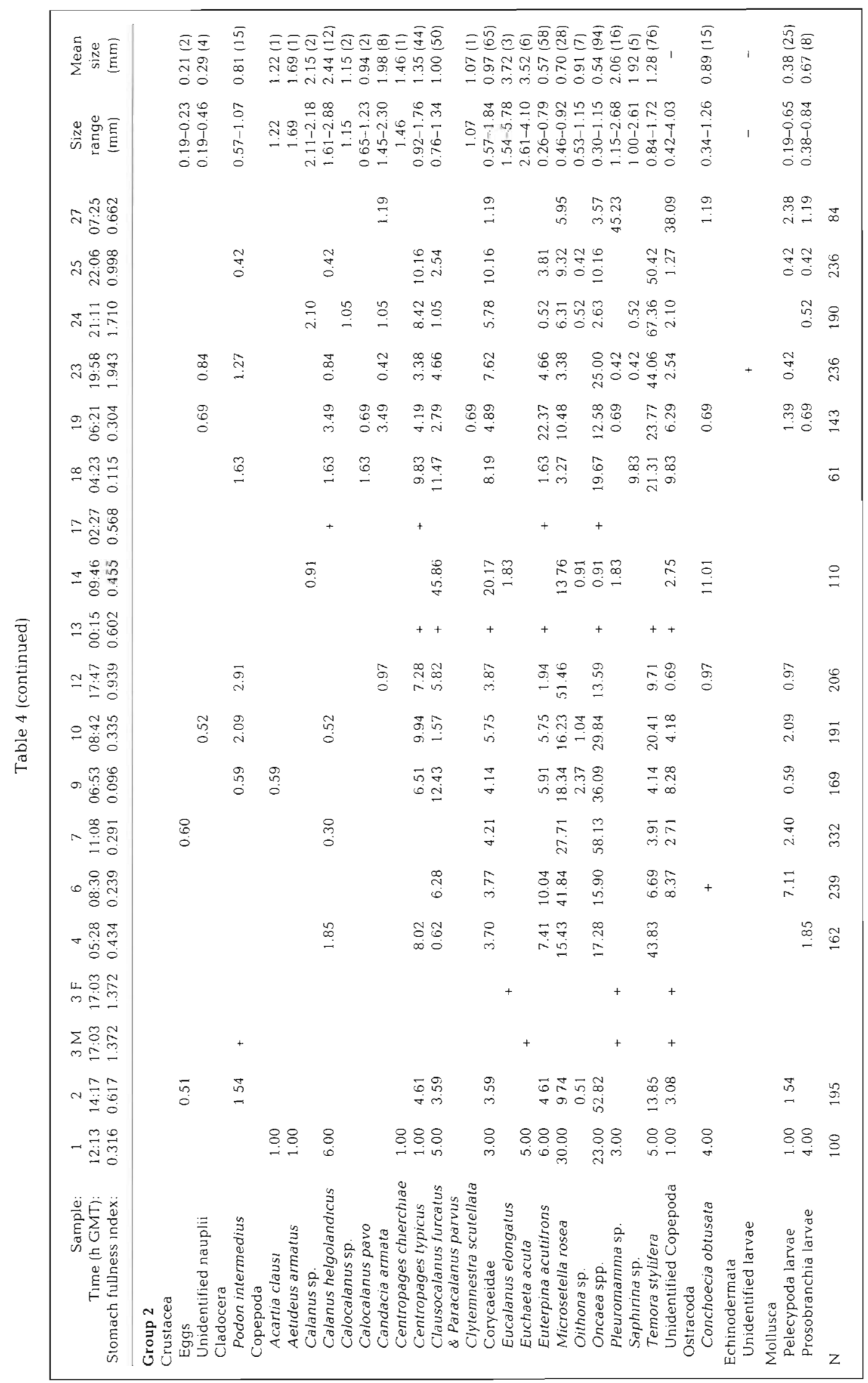




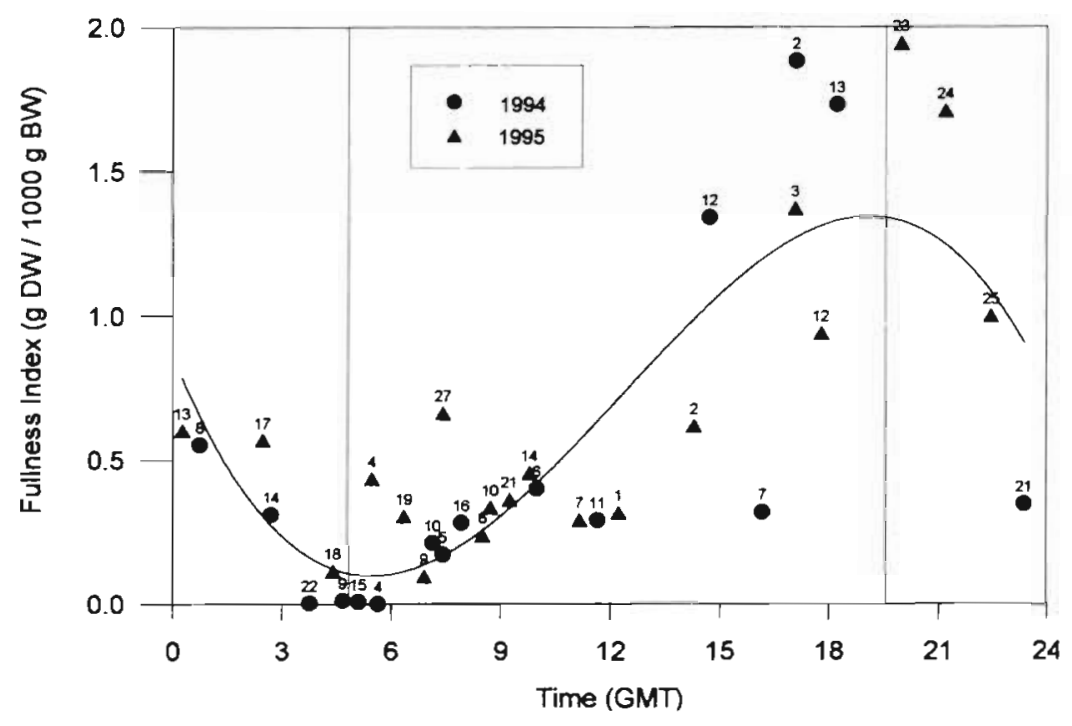

Fig. 3. Engraulis encrasicolus. Plot of mean stomach fullness index values for the 1994 and 1995 anchovy samples on a notional daily cycle. A third-degree polynomial was fit to the data to highlight the daily fullness pattern. Light and dark cycle is indicated by the 2 vertical lines. Sample numbers are given over the data points

anchovy feed primarily on copepods, which predominate both in number and in biomass in most of the samples analysed. On a few occasions only, the contributions of other groups in the food bolus rivalled that of copepods. These included cladocerans (sample $13^{94}$, i.e. sample 13 from GICS-94), mysids (samples $14^{94}$, $4^{95}, 24^{95}, 25^{95}$ ), decapod larvae (samples $1^{95}, 24^{95}, 25^{95}$ ),

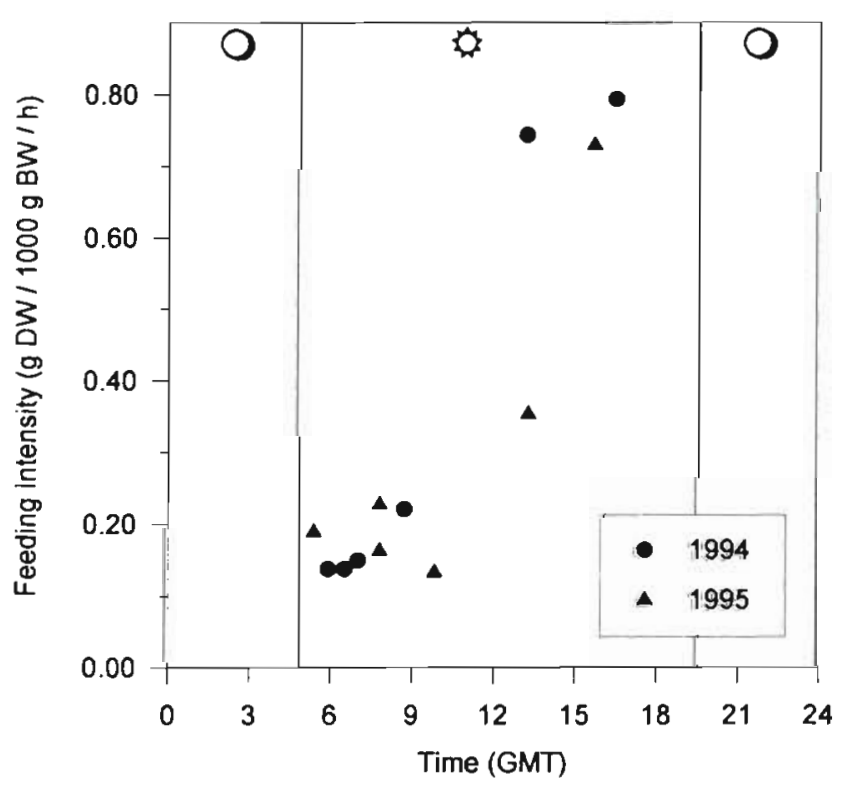

Fig. 4. Engraulis encrasicolus. Plot of feeding intensity rates calculated from 1994 and 1995 samples on a notional diel cycle. Light and dark cycle is indicated euphausiids (sample $1^{90}$ ), amphipods (sample $27^{45}$ ), appendicularians (sample $19^{95}$ ), and pteropods (samples $18^{45}$, $24^{95}, 25^{95}$ ).

Nychthemeral and interannual temporal analysis and spatial analysis of the composition of the anchovy diet revealed variability partly ascribable to the following factors: (1) The succession stage in the zooplanktonic populations during the sampling period. (2) Time of day. (3) Geographic location of shoals or individuals with respect to bottom depth and hydrological conditions.

(1) The level and geographical distribution of consumption of certain key species that are indicators of summer and winter zooplanktonic facies were suggestive of differences in the annual succession in the plankton between the 2 sampling periods and hence of differences in the stratification of the water column. This was quite evident in the copepods (Fig. 5). On the GICS-94 survey anchovy feeding was largely dependent upon Centropages typicus, the main indicator species of the winter facies in the copepod population of the Mediterranean coast of Spain (Estrada et al. 1989). On the GICS-95 survey, feeding concentrated on Temora stylifera, the most characteristic species in the summer zooplankton facies (Estrada et al. 1989). Inshore preferential consumption of other typically summer species such as Euterpina acutifrons (Vives 1966) and copepods of the Family Corycaeidae (Estrada et al. 1989) during the 1994 survey furnishes additional, more indirect evidence of such interannual differences.

Parallel hydrological studies carried out concurrently with the 2 surveys (Salat et al. 1996) showed that while thermal stratification of the water column was detected in both sampling periods, heavy winds about $12 \mathrm{~d}$ before the start of the 1995 survey had thoroughly mixed the upper $30 \mathrm{~m}$ of the water column. Since the thermocline was initially located at around $20 \mathrm{~m}$, this phenomenon brought about a sudden increase in temperature below that layer (more than $1^{\circ} \mathrm{C}$ at $30 \mathrm{~m}$ ). This could account for the development of a summer zooplankton facies.

(2) Only the presence of fresh decapod larvae, mysids, cumaceans (a single individual in sample $14^{94}$ ) and pteropods as prey items furnished evidence of nocturnal predation by anchovies (Tables $3 \& 4$ ). Except for an isolated instance of consumption of the pteropod Creseis acicula, nocturnal predation was limited to only the first 2 taxa listed above, regularly pre- 
sent at that time of day. Still, the low levels of stomach fullness associated with the episodes of nocturnal predation are suggestive of the sporadic nature of such feeding, which appears to be entirely marginal. It is also important to note that the few taxa consumed at night are appreciably larger in size than most of the prey items consumed during the daytime (see Tables 3 \& 4).

(3) Feeding on certain taxa that tend to aggregate at subsurface or mesopelagic levels, such as the euphausiid Stylocheiron longicorne and the isopods and copepods Pleuromamma sp., Euchaeta acuta, and Eucalanus elongatus would appear to be associated with the area of the shelf where it broadens out north of the Ebro Delta. The existence of permanent upwelling in this area caused by the interaction between the Liguro-Provençal-Catalan current flowing along the coast in a southwesterly direction and the broad shelf composed of sediment from the Ebro River described by Font et al. (1990) was recorded during both sampling periods (Salat et al. 1996). These conditions may favour the presence of the above-mentioned taxa over the shelf. Additionally, the mere proximity of the slope may, irrespective of other factors, suffice to favour predation on these taxa. This could explain the presence of the copepod $E$. elongatus and the ostracod Conchoecia obtusata in sample $14^{95}, 2$ species that are usually found in deeper layers in the study area in summer (Vives 1966).

Correspondence analysis of the abundance values for the most frequent Group 2 prey items clearly reflected certain elements of these patterns. Table 5 presents the eigenvalues and the percentage of the variance explained for the first 3 factors. Fig. 6 graphically represents the 24 samples and 16 prey categories included in the analysis plotted on the axes for the first 2 factors. There was a tendency for most of the samples on the 1994 and 1995 surveys to fall into 2 separate groupings, reflecting interannual differences in succession within the copepod population. Sample groupings $1^{95}$ and $14^{95}$ and $2^{94}$ and $27^{95}$ reflected unusual levels of consumption of the

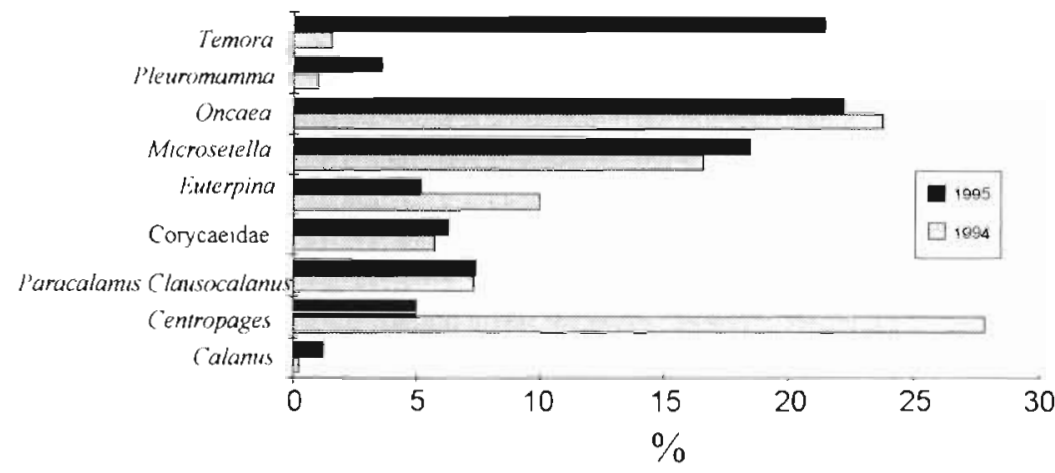

Fig. 5. Engraulis encrasicolus. Relative frequency of the main copepod species in the anchovy diet on the 1994 and 1995 surveys. Results are percentages of total copepod prey items

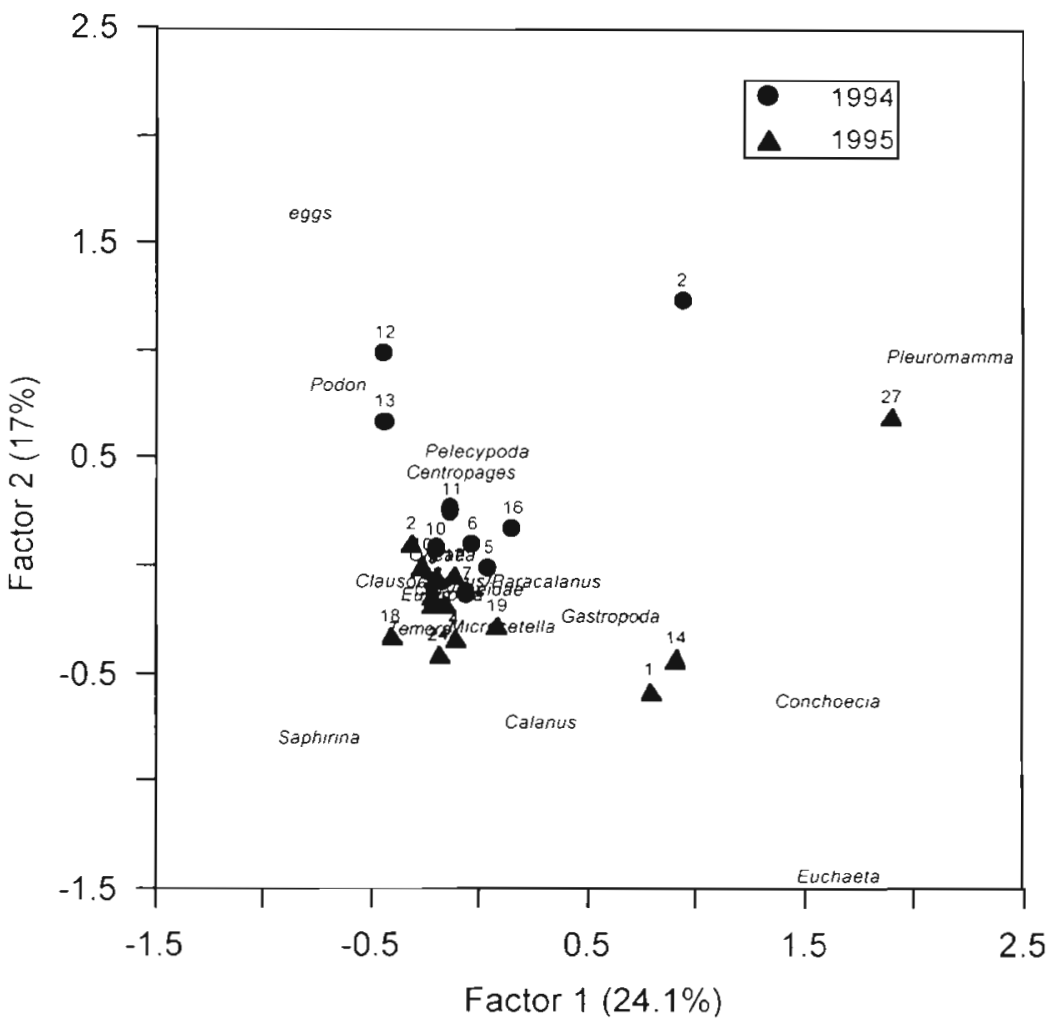

Fig. 6. Engraulis encrasicolus. Plot of samples and prey taxa on the axes for the first 2 factors from the correspondence analysis run on the abundances of the most important Group 2 prey items

Table 5. Engraulis encrasicolus. Eigenvalues and percentage of the variance explained by the first 3 factors obtained by correspondence analysis using data on the freguency of the most important Group 2 taxa in the samples

\begin{tabular}{|lrrc|} 
& Factor 1 & Factor 2 & Factor 3 \\
\hline Eigenvalue & 0.22 & 0.16 & 0.13 \\
\% variance & 24.10 & 17.00 & 14.15 \\
\hline
\end{tabular}


species Conchoecia obtusata and Pleuromamma sp. respectively, 2 characteristic taxa of deep layers. Sample grouping $12^{94}$ and $13^{94}$ probably reflected a local abundance of the cladoceran Podon intermedius.

Calculation of the daily ration by Tudela \& Palomera (1995) enabled us to assess the impact of anchovy on the pelagic food web and the magnitude of the energy flow channelled through the spawning population in the study area. This result was then compared with production at lower trophic levels.

An acoustic survey carried out in the summer of 1993 (Garcia 1994) placed the biomass of the spawning anchovy stock in the area of the shelf between Castelló de la Plana and Barcelona (Catalan Sea, NE Spain) at $7066 \mathrm{t}$. This region, covering a surface area of $9833 \mathrm{~km}^{2}$, encompasses the entire spawning area off southern Catalonia, the sampling area in the present study. Taking a daily ration of $34.1 \mathrm{cal} \mathrm{g}^{-1}$ (Tudela \& Palomera 1995), consumption by that amount of biomass would be $2.40 \times 10^{11} \mathrm{cal} \mathrm{d}^{-1}$. In addition, the mean value of zooplankton between $53 \mu \mathrm{m}$ and $1 \mathrm{~cm}$ in size per $\mathrm{m}^{2}$ of water column on the shelf between Castelló de la Plana and Barcelona was calculated based on the values collected at 36 stations sampled in the summer of 1992 (García 1994). The resulting value, $477.1 \mathrm{mg}$ DW $\mathrm{m}^{-2}$, was converted to calorie units based on the caloric content of the anchovy diet calculated by Tudela \& Palomera (1995). This calculation was for the entire area covered by the acoustic assessment of anchovy biomass referred to above and yielded a value of $2.70 \times 10^{13}$ cal. In addition, Calbet et al. (1996) obtained mean production values of 2.15 and $6.6 \% \mathrm{mg}$ $\mathrm{C}_{\text {eggs }} \mathrm{mg}^{-1} \mathrm{C}_{\text {female }} \mathrm{d}^{-1}$ for 5 copepod species at 2 stations located on a transect perpendicular to the coast off Barcelona sampled in June 1993. Applying the average of these 2 values to the zooplankton biomass in the study area yielded a production value of $1.18 \times$ $10^{12} \mathrm{cal} \mathrm{d}^{-1}$. Comparing this value to the value for consumption of the anchovy parent stock, previously estimated at $2.40 \times 10^{11} \mathrm{cal} \mathrm{d}^{-1}$, indicated that the fraction of zooplankton production accessible to anchovy for daily consumption was $20.3 \%$.

\section{DISCUSSION}

The results obtained show that during the spawning period anchovy in the study area were exclusively zooplanktivorous. These findings contrast with the results of other researchers working on this species during the spawning periods in the Black Sea-Sea of Azov (Mikhman \& Tomanovich 1978, Bulgakova 1993a), who recorded sporadic feeding on phytoplankton.

Acoustic readings on the 1994 survey disclosed the well-known pattern of vertical migration characteristic of small pelagics (Fig. 7), also reflected by the depth of positive tows and the type of prey consumed during the day. Thus, evidence to date appears to indicate that anchovies form well-defined shoals in the lower half of the water column during the daytime. During that part of the day individuals feed mainly on small prey items (usually smaller than $2 \mathrm{~mm}$ in size), basically copepods and, to a lesser extent, cladocerans, molluscan larvae, ostracods, and other taxa, though they may also prey on larger prey items, such as amphipods, decapod larvae, appendicularians, polychaetes, fish eggs and larvae, etc. Diurnal feeding intensifies from midday to a peak in the afternoon until sunset, after which feeding activity falls of abruptly and anchovy migrate to levels closer to the surface. At night, anchovy shoals spread out considerably and feeding is sporadic at very low levels. When feeding does occur, it is concentrated on large prey such as decapod larvae, mysids, pteropods, and cumaceans. This same pattern was repeated on the 2 surveys carried out at the same time of year in 2 consecutive years, thus strengthening the representativeness of these findings for anchovy in the study area.

To date, the only studies on the feeding dynamics of the European anchovy have been confined to the Black Sea-Sea of Azov region. Okul (1940) reported 2 stomach fullness peaks in anchovy in the Sea of Azov (9:00 to $10: 00 \mathrm{~h}$ and $18: 00 \mathrm{~h})$ and stated that feeding intensity dropped off at night. Conversely, Mayorova \& Chugunova (1954) described heavy feeding on mysids by anchovy in the Black Sea at night. Mikhman \&
Trawl 12 (1994)

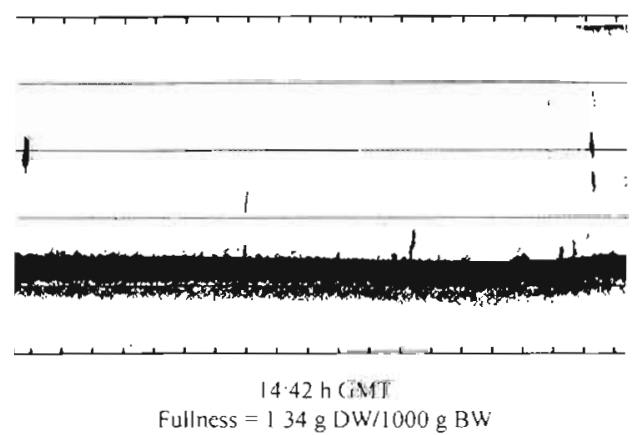

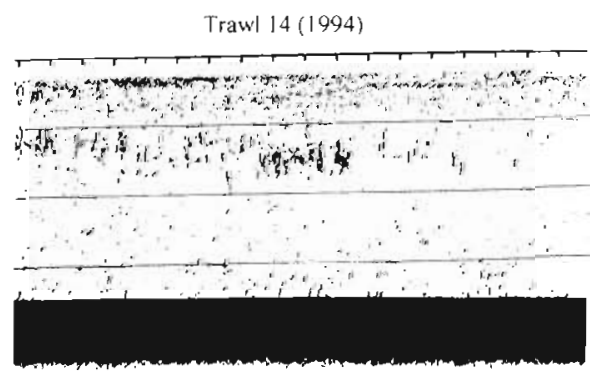

$02.42 \mathrm{~h} \mathrm{GMT}$ Fullness $=030 \mathrm{~g} \mathrm{DW} / 1000 \mathrm{~g} \mathrm{BW}$
Fig. 7. Representative acoustic echograms showing aggregations of small pelagics in the daytime and at night ( $20 \mathrm{~m}$ horizontal intervals are indicated) 
Tomanovich (1978) reported a feeding pattern for anchovy in the Sea of Azov in summer very similar to the one described in the present study. They recorded a daily pattern based on copepods with a stomach fullness peak at 20:00 h and sporadic nighttime feeding on large prey items such as polychaetes, mysids, and cumaceans. In contrast, in a study also carried out in summer, Sirotenko \& Danilevskiy (1978) described 2 daily stomach fullness peaks in anchovy in the Black Sea (one between 19:00 and 22:00 h and the other between 15:00 and 16:00 h). They again reported a predominance of copepods in the diet. Finally, based on field studies and laboratory work, Bulgakova (1993a) postulated particulate feeding by anchovy in the Black Sea during the spawning period, basically on copepods and cladocerans, replaced by filter feeding of small prey during the hours of darkness, with the sole exception of mysids and other bioluminescent prey items, which may be actively consumed at night. This hypothesis, assuming particulate feeding to be light dependent, contrasts with the results of the study by O'Connell (1963), who demonstrated the high acuity of vision in Engraulis mordax in conditions of low light intensity.

Studies of other congeneric species have not revealed uniform patterns of trophic behaviour. While many have reported a predominance of zooplankton in the diet (Angelescu \& Anganuzzi 1981 in Engraulis anchoita; James 1987 in E. capensis; Loukashkin 1970 and Koslow 1981 in E. mordax; Hayasi 1967 in $E$. japonicus), others have found the diet to be based on phytoplankton (King \& Macleod 1976 in E. mordax; Longhurst 1971, and Rojas de Mendiola 1971 in E. ringens). Still greater discrepancies exist with respect to the diel feeding cycle. Angelescu \& Anganuzzi (1981) and James (1987) described a pattern of nocturnal feeding, while the data published by Armstrong et al. (1991) for E. capensis and Loukashkin (1970), Koslow (1981), and Valdés et al. (1987) for E. capensis were suggestive of heavy feeding during the daytime. Rojas de Mendiola (1971) described 3 periods of intense feeding activity in the Peruvian anchoveta E. ringens during the diel cycle. Considering the relationship between feeding behaviour and the location of individuals in the water column, James (1987) reported that feeding in E. capensis intensified during the interval in which individuals carried out a vertical migration towards the surface at sunset. In E. mordax, on the other hand, various studies performed off California, USA, all described the presence of large shoals actively feeding at the surface during the daytime (Loukashkin 1970, Mais 1974, Koslow 1981).

The Western Mediterranean, like other temperate and tropical seas throughout the world, exhibits marked thermal stratification of the water column in the summer. Such conditions are conducive to the development of a deep chlorophyll maximum (DCM) and an associated deep zooplankton maximum (DZM) (Harris 1988). Alcaraz (1985) studied the vertical distribution of the zooplankton in the Catalan Sea in summer and found the DCM to be located just above the thermocline at depths of between 70 and $90 \mathrm{~m}$. During the daytime the DCM coincided with a DZM (mesozooplankton), such that on occasion up to $60 \%$ of the total zooplankton biomass was concentrated in a layer only $10 \mathrm{~m}$ thick. Working in the same area, Saiz \& Alcaraz (1990) reported that $93 \%$ of the adult population of the copepod Centropages typicus, as already discussed above a key species in the feeding of Engraulis encrasicolus, was concentrated at the DCM during the daytime. At night, on the other hand, when the total biomass of the species was more broadly distributed through the water column, $63 \%$ of individuals rose through the thermocline to the surface layer.

Hydrological studies carried out during both sampling periods in the present study also detected a welldefined DCM (Salat et al. 1996). During 1994, the fluorescence peak was located just below the thermocline, at a mean depth of between 10 and $50 \mathrm{~m}$, depending on bottom depth, whereas during 1995 the peak was located at a mean depth of $40 \mathrm{~m}$. Acoustic readings indicated the presence of shoals of small pelagic fish at those depths during the daytime (Fig 7).

The results presented in this paper suggest that during the spawning period predation by anchovy Engraulis encrasicolus off the coast of Catalonia may be concentrated on the zooplankton that collects in the DCM stratum during the daytime. The increased density of zooplankton biomass in that stratum would allow high predation rates by anchovy, and the low levels of feeding at night suggest that anchovy were able to satisfy their energy requirements during the daytime.

The reported differences in the feeding behaviour of the species of the genus Engraulis, observed even within the same species, may thus be attributable to differences in prey availability in response to the existence of differing hydrographic structures in the respective distribution areas considered. Focusing on the spawning period, during which many of the studies cited above were completed, the different species of anchovy are serial spawners (Alheit 1993), and studies on $E$. mordax indicate that most of the energy required for spawning has to be obtained from the food consumed during the spawning period itself (Hunter \& Leong 1981). Bearing in mind that these species are trophic opportunists with versatile predation patterns, the variability reflected in previous studies falls into place. Thus, several studies have reported higher filter-feeding activity and extended feeding periods when food availability was limiting. Mikhman \& 
Tomanovich (1978) reported that when zooplankton biomass dropped, anchovy E. encrasicolus in the Sea of Azov replaced copepods in their diet with phytoplankton. James (1987) attributed the feeding behaviour of E. capensis described by Valdés et al. (1987) on the Agulhas Bank, to be characterized by diurnal feeding and high cannibalism rates, and the pattern he described in the same area, namely, an unusually protracted feeding period, to the effects of trophic limitation in that area.

Because some stomachs contained very small prey items together with much larger prey items, clear conclusions regarding the feeding method employed during the daytime cannot be drawn. James \& Findlay (1989) reported that Engraulis capensis employed filter feeding for prey items smaller than $0.71 \mathrm{~mm}$ but particulate feeding for prey items larger than that size. Their findings concur with those of O'Connell (1972) and Koslow (1981) on E. mordax, which considered particulate feeding to be more effective than filter feeding, translating into a preference for larger prey. Hunter \& Dorr (1982), on the other hand, placed the critical size of prey items at which E. mordax switched from filter feeding to particulate feeding at between 1 and $3 \mathrm{~mm}$. Our results could be in consonance both with alternation between particulate feeding and filter feeding and with the 'mixed feeding' described by James \& Findlay (1989) in E. capensis, comprising particulate feeding on large prey items concurrently with filter feeding on smaller ones.

The virtual absence of cannibalism on anchovy eggs in the present study (only 3 of the 72 fish eggs identified in the stomach contents were anchovy eggs) is noteworthy in that it is an exception to other findings on congeneric species. Angelescu (1982) reported cannibalism in Engraulis anchoita in Argentina. Valdés et al. (1987) attributed $70 \%$ of the mortality on E. capensis eggs in the Agulhas Bank area, characterized by high egg density levels, to cannibalism. Valdés Szeinfeld (1991) and Valdés Szeinfeld \& Cochrane (1992) considered cannibalism to exercise an important density dependent regulatory function on populations of $E$. capensis. Kubo (1961) reported cannibalism in $E$. japonicus in Japan. Laboratory studies on E. mordax have indicated that eggs are ingested during filter feeding and that egg densities of 1 to 2 eggs $1^{-1}$ are sufficient to trigger filter-feeding activity (Hunter \& Dorr 1982). Hunter \& Kimbrell (1980) noted that a shoal of that species may consume up to $48 \%$ of the eggs present. Applying MacCall's (1980) modification to Hunter \& Kimbrell's (1980) assessment of cannibalism for the Southern California Bight, Alheit (1987) reported that cannibalism accounted for $28 \%$ of egg mortality in E. mordax. That same author reported a $21.9 \%$ share of egg mortality in E. ringens in Peru.
Various studies have indicated that the vertical distribution of Engraulis encrasicolus eggs is confined to the surface layers (Varagnolo 1965, Ghirardelli 1967. Specchi 1968, Regner 1972, Palomera 1991, Niermann et al. 1994). Extrapolating this phenomenon to other congeneric species suggests that the high levels of cannibalism recorded in E. capensis, E. mordax, and E. ringens can only be attributed to intense filter-feeding activity at the surface. Existing observations in the studies already mentioned above of shoals of E. mordax feeding at the surface during the spawning period would appear to bear out that hypothesis.

The confinement of predation activity to the daytime and to subsurface strata reported in this study results in the spatio-temporal segregation of feeding and spawning activity. While feeding activity takes place roughly from 05:00 to 19:00 $\mathrm{h}$ in the Catalan Sea, spawning takes place from 20:00 to 04:00 h (García \& Palomera 1996). Palomera (1991) reported that over $95 \%$ of anchovy eggs were confined to the uppermost $10 \mathrm{~m}$ in the same study area and inferred, from the very small range of variation in egg density derived of the low volume of the perivitelline space, that spawning occurred in that same stratum, above the thermocline. Acoustic readings made during the present study recorded a typical nocturnal pattern of vertical migration of shoals of small pelagics towards the surface and subsequent dispersal of individuals (see Fig. 7). Without intending to postulate any causal relationship, it would appear that trophic dynamics characterized by confinement of predation to subsurface layers where no eggs are present is not conducive to cannibalism in the diet of anchovy in the Catalan Sea.

In addition, egg concentrations recorded in the sampling area (García \& Palomera 1996) appear to be substantially lower than those in other areas where cannibalism rates are high for congeneric species (Hunter \& Kimbrell 1980, Santander et al. 1983, Valdés et al. 1987). According to certain researchers the level of cannibalism is highly dependent on egg density levels (Hunter \& Kimbrell 1980, Valdés et al. 1987, Valdés Szeinfeld 1991). It seems reasonable therefore to expect little potential cannibalism in the Catalan Sea.

Other ecological factors could also contribute to the absence of cannibalism in our study. Many studies have indicated that pilchard of the genus Sardinops are more efficient predators of anchovy eggs than are adult anchovy (Santander et al. 1983, Valdés Szeinfeld 1991). Valdés Szeinfeld (1991) reported that consumption of Engraulis capensis eggs by Sardinops ocellatus off South Africa in 1986 was 3 times higher than cannibalism, even though pilchard biomass was an order of magnitude lower than anchovy biomass. Off the Mediterranean coast of Spain, in comparison, the pilchard Sardina pilchardus is more abundant than 
anchovy. Acoustic assessments carried out in the spawning area considered in the present paper during the anchovy spawning period yielded a pilchard biomass of $31200 \mathrm{t}$ as opposed to only $22600 \mathrm{t}$ of anchovy (Palomera 1995). If the ability of $S$. pilchardus to prey on anchovy eggs was comparable to that of other species in the genus Sardinops, the former could make a very significant contribution to the regulation of the anchovy population in the Catalan Sea, similar to the effect of $S$. ocellatus on E. capensis off South Africa (Valdés Szeinfeld \& Cochrane 1992). Detailed studies of summer feeding in pilchard in the sampling area are needed to verify this hypothesis. Certain indications suggest that this may be the case. Massuti \& Oliver (1948) underlined the particular abundance of anchovy eggs in the stomachs of pilchard between June and August' off Menorca (Catalan Sea). This hypothesis is also applicable to other less abundant pelagic fish in the area, e.g Sardinella aurita.

The consumption of biological production by the Engraulis encrasicolus population in the study area (20.3\% of zooplankton production), highlights the major impact of this species in channelling energy through the pelagic food web of the Catalan Sea. Studies on other engraulids suggest that the present findings for E. encrasicolus are not an exception in this group. Koslow (1981) estimated that E. mordax consumed between 10 and $100 \%$ of secondary production in the southern California Bight, and Luo \& Brandt (1993) reported that Anchoa mitchilli consumed onethird of the total zooplankton production during the period of maximum feeding activity in Chesapeake Bay, USA.

As already stated above, pilchard are more abundant than anchovy in the Catalan Sea (Palomera 1995) and appear to feed on both phytoplankton and zooplankton (Massutí \& Oliver 1948). Combined predation by pilchards and anchovies likely accounts for consumption of a large proportion of daily zooplankton production in this region.

Acknowledgements. This research was supported by a grant from CIRIT (the Catalonian Commission on Research) awarded to S.T Samples were collected under the T-ECHO UE Project (Ref. AIR1-CT92-0314). Dr R. Torres and Dr 1. Lombarte assisted with sampling on board the survey vessel. Dr J. Cartes and 2 anonymous referees made valuable comments on the original manuscript.

\section{LITERATURE CITED}

Alcaraz M (1985) Vertical distribution of zooplankton biomass during summer stratification in the Western Mediterranean. In: Gibbs PE (ed) Proceedings of the 19th Eur Mar Biol Symp. Cambridge University Press, Cambridge, p 135-143
Alheit $\mathrm{J}$ (1987) Egg cannibalism versus egg predation: their significance in anchovies. In: Payne AlL, Gulland JA, Brink KH (eds) The Benguela and comparable ecosystems. S Afr J Mar Sci 5:467-470

Alheit J (1993) Use of the dally egg production method for estimating biomass of clupeoid fishes: a review and evaluation. Bull Mar Sci 53:750-767

Angelescu $V$ (1982) Ecología trólica de la anchoíta del Mar Argentıno (Engraulidae, Engraulis anchoita). Parte ll. Alimentación, comportamiento y relaciones tróficas en el ecosistema. Contrib Inst Nac Invest Des Pesq 409:1-83

Angelescu V, Anganuzzi A (1981) Resultados sobre la alimentación de la anchoíta (Engraulis anchoita) en el área explotada por el B/L 'Shinkai Maru' durante les campanas VI $(21-9-78 / 12-10-78)$ y VIII $(20-11-78 / 19-12-78)$ en e] Mar Argentino. Contrib Inst Nac Invest Des Pesq 383: $281-298$

Armstrong MJ, James AG, Valdés Szeinfeld ES (1991) Estimates of annual consumption of food by anchovy and other pelagic fish species off South Africa during the period 1984-1988. S Afr J Mar Sc1 11:251-266

Bulgakova Y (1993a) Daily feeding dynamics of the Black Sea anchovy, Engraulis encrasicolus. J Ichthyol 33:78-88

Bulgakova Yu (1993b) Intensity of feeding of the Black Sea anchovy, Engraulis encrasicolus, during the spawning period. J Ichthyol 32:146-151

Calbet A, Alcaraz M, Saiz E, Estrada M, Trepat I (1996) Planktonic herbivorous food webs in the Catalan Sea (NW Mediterranean): temporal variability and comparison of indices of phyto-zooplankton coupling based on state variables and rate processes. J Plankton Res 18:2329-2347

Cuadras CM (1991) Métodos de análisis multivariante. PPU. Barcelona

Eggers DM (1977) Factors in interpreting data obtained by diel sampling of tish stomachs. J Fish Res Bd Can 34: $290-294$

Elliott JM, Persson L (1978) The estimation of daily rates of food consumption for fish. J Anim Ecol 47:977-993

Estrada M, Vives F, Alcaraz M (1989) Vida y producción en mar abierto. In: Margalef R (ed) El Mediterráneo Occidental. Omega, Barcelona, p 150-199

Font J, Julià A, Rovira J, Salat J, Sánchez-Pardo J (1990) Circulación marina en la plataforma continental del Ebro a partir de la distribución de masas de agua y los microcontaminantes orgánicos en el sedimento. Acta Geol Hisp 21/22:483-489

García A (coord) (1994) Northwestern Mediterranean anchovy: distribution, biology, fisheries and biomass estimation by different methods. Final Report Study, Contract FAR Project MA 3.370. UE DG XIV, Brussels (mimeo)

García A. Palomera l (1996) Anchovy early life history and its relation to its surrounding environment in the western Mediterranean basin. Sc1 Mar 60(Suppl 2):155-156

Ghirardelli E (1967) Microdistribuzione superficiale del plancton del Golfo di Trieste. Metodi di racolta, primi resultati. Boll Soc Adriat Sci Trieste 55:18-26

Harris RP (1988) Interactions between diel vertical migratory behaviour of marine zooplankton and the subsurface chlorophyll maximum. Bull Mar Sci 43:663-674

Hayasi S (1967) A note on the biology and fishery of the Japanese anchovy, Engraulis japonica (Houttuyn). Calif Coop Oceanic Fish Invest Rep 11:44-57

Hunter JR, Dorr H (1982) Thresholds for filter feeding in northern anchovy, Engraulis mordax. Calif Coop Oceanic Fish Invest Rep 23:198-204

Hunter JR, Kimbrell CA (1980) Egg cannibalism in the northern anchovy, Engraulis mordax. Fish Bull 78:811-816 
Hunter JR, Leong $R$ (1981) The spawning energetics of female Northern anchovy, Engraulis mordax. Fish Bull 79 $215-230$

James AG (1987) Feeding ecology, diet and field-based studles on feeding selectivity of the Cape anchovy Engraulis capensis Gilchrist. In: Payne AIL, Gulland JA, Brink KH (eds) The Benguela and comparable ecosystems. S Afr J Mar Sci 5:673-692

James AG. Findlay KP (1989) Effect of particle size and concentration on feeding behaviour, selectivity and rates of food ingestion by the Cape anchovy Engraulis capensis Mar Ecol Prog Ser 50:275-294

King DPF, Macleod PR (1976) Comparison of the food and the filtering mechanism of pilchard Sardinops ocellata and anchovy Engraulis capensis off South West Africa, 1971-1972. Investl Rep Sea Fish Branch S Afr 111:1-29

Koslow JA (1981) Feeding selectivity of schools of northern anchovy, Engraulis mordax, in the Southern California Bight. Fish Bull 79:131-142

Kubo I (1961) Suisan Sigen Kakuron. Koseisya-Koseikaku, Tokyo

Longhurst AR (1971) The clupeoid resources of tropical seas Oceanogr Mar Biol Annu Rev 9:349-385

Loukashkin AS (1970) On the diet and feeding behaviour of the northern anchovy, Engraulis mordax (Girard). Proc Calif Acad Sci 37:419-458

Luo J, Brandt SB (1993) Bay anchovy Anchoa mitchilli production and consumption in mid-Chesapeake Bay based on a bioenergetics model and acoustic measures of fish abundance. Mar Ecol Prog Ser 98:223-236

MacCall AD (1980) The consequences of cannibalism in the stock-recruitment relationship of planktivorous fishes such as Engraulis. In: Sharp GD (ed) Workshop on the effects of environmental variation on the survival of larval pelagic fishes. IOC Workshop Rep 28:201-220

Mais KF (1974) Pelagic fish surveys in the California Current Calif Dep Fish Game Fish Bull 162:1-79

Massutí M, Oliver M (1948) Estudio de la biometría y biología de la sardina de Mahón (Baleares), especialmente de su alimentación. Bol Inst Esp Oceanogr 3:1-13

Mayorova AA, Chugunova NI (1954) Biology, distribution, and stock estimate of Black Sea anchovy. Tr Vses $\mathrm{N}$-i In-ta Morsk Rybn Kh-va i Okeanogr 28:5-33

Mikhman AS, Tomanovich LV (1978) The feeding of the Azov anchovy, Engraulis encrasicholus maeoticus. J Ichthyol 17 . $240-244$

Motos L (1996) Reproductive biology and fecundity of the Bay of Biscay anchovy population (Engraulis encrasicolus L.). Sci Mar 60(Suppl 2):195-207

Niermann $U$, Bingel $F$, Gorban A, Gordina $A D$, Gücü $A C$, Kideys AE, Konsulov A, Radu G, Subbotin AA, Zaika VE (1994) Distribution of anchovy eggs and larvae (Engraulis encrasicolus Cuv.) in the Black Sea in 1991-1992. ICES J Mar Sci 51:395-406

Nikitin VN (1946) Feeding of the anchovy (Engraulis encrasicolus L.) along the Georgian coast of the Black Sea. Tr Zoologicheskogo Instituta AN Grus SSR 6:1-64

O'Connell CP (1963) The structure of the eye of Sardinops caerulea, Engraulis mordax, and four other pelagıc marine teleosts. J Morphol 113:287-330

$\mathrm{O}^{\prime}$ Connell CP (1972) The interrelation of biting and filtering in the feeding activity of the northern anchovy (Engraulis mordax). J Fish Res Bd Can 29:285-293

Okul AV (1940) Feeding and diet of planktivorous fish in the Sea of Azov. Tr Azovo-Chzernomorsk $\mathrm{N}$-i in-ta Morsk Rybn Kh-va i Okeanogr 12:97-148
Palomera I (1991) Vertical distribution of eggs and larvae of Engraulis encrasicolus in stratified waters of the western Mediterranean. Mar Biol 111:37-44

Palomera I (1992) Spawning of anchovy Engraulis encrasicolus in the Northwestern Mediterranean relative to hydrographic features in the region. Mar Ecol Prog Ser 79: $215-223$

Palomera I (ed) (1995) Avaluació de les poblacions de peix blau a la Costa Catalana el 1994. Final report, Departament d'Agricultura, Ramaderia i Pesca de la Generalitat de Catalunya, Barcelona (mimeo)

Palomera I, Rubiés P (eds) (1996) The European anchovy and its environment. Sci Mar 60(Suppl 2)

Pertierra JP, Lleonart J (1996) NW Mediterranean anchovy fisheries. Sci Mar 60 (Suppl 2):257-267

Regner S (1972) Contribution to the study of the ecology of the planktonic phase in the life history of the anchovy, Engraulis encrasicolus (Linnaeus, 1978), in the central Adriatic. Acta Adriat 1.4(9):1-40

Rojas de Mendiola B (1971) Some observations of the feeding of the Peruvian anchoveta Engraulis ringens $J$ in two regions of the Peruvian coast. In: Costlow JD (ed) Fertility of the sea, Vol 2. Gordon and Breach. New York, p $417-440$

Saiz E, Alcaraz M (1990) Pigment gut contents of copepods and deep phytoplankton maximum in the Western Mediterranean. J Plankton Res 12:665-672

Salat J, Lloret M, Sánchez J (1996) Catalan Sea and Adriatic Sea hydrography during T-ECHO Project cruises (years 1993 to 1995). In: Rucabado J, Schneider P (eds) T-ECHO Project Final Report, AIR-1 CT92 0314, Brussels, p 1-25 (mimeo)

Santander H, Alheit J, MacCall AD, Alamo A (1983) Egg mortality of the Peruvian anchovy Engraulis ringens caused by cannibalism and predation by sardines Sardinops sagax. In: Sharp GD, Csirke J (eds) Proceedings of the expert consultation to examine changes in abundance and species composition of neritic fish resources. San José, Costa Rica, April 1983. FAO Fish Rep 291(3):1012-1025

Sirotenko MD, Danilevskiy NN (1978) Quantitative feeding indices of the Black Sea anchovy, Engraulis encrasicolus ponticus. J Ichthyol 17:610-617

Specchi M (1968) Observations preliminaires sur l'hyponeuston du Golfe de Trieste. Rapp PV Réun Comm Int Explor Scient Mer Méditerr 19:491-494

Tudela S, Palomera I (1995) Diel feeding intensity and daily ration in the anchovy Engraulis encrasicolus in the northwest Mediterranean Sea during the spawning period. Mar Ecol Prog Ser 129:55-61

Valdés ES, Shelton PA, Armstrong MJ, Field JG (1987) Cannibalism in South African anchovy: egg mortality and egg consumption rates. In: Payne AlL, Gulland JA, Brink KH (eds) The Benguela and comparable ecosystems. S Afr J Mar Sci 5:613-622

Valdés Szeinfeld E (1991) Cannıbalism and intraguild predation in clupeoids. Mar Ecol Prog Ser 79:17-26

Valdés Szeinfeld ES, Cochrane KL (1992) The potential effects of cannibalism and intraguild predation on anchovy recruitment and clupeoid fluctuations. In: Payne AlL, Brink KH, Mann KH, Hilborn R (eds) Benguela trophic functioning. S Afr J Mar Sci 12:695-702

Varagnolo S (1965) Alcune osservazioni sulla distribuzione delle uova gallegianti di Teleostei nee'Alto Adriatico. Boll Zool 32:849-858

Vives F (1966) Zooplancton nerítico de las aguas de Castellón (Mediterráneo occidental). Invest Pesq 30:49-166

Submitted: July 2, 1997; Accepted: October 8, 1997

Proofs received from author(s): December 8, 1997 